\title{
DREADED ANNIVERSARIES: THE CULTURAL REVOLUTION AND MAO ZEDONG \\ Lorand Laskai
}

O N 16 MAY, the fiftieth anniversary of the start of the Cultural Revolution, the People's Daily 人民日报, the mouthpiece of the CCP, published a rare commentary acknowledging the decade-long movement's errors and costs. Putting quotation marks around the phrase 'Cultural Revolution' (a longstanding practice since at least the 1980s), it described the period as 'a major complication in the development of our Party and country'. The commentary concluded that 'We must certainly fix in our memories the historic lessons of the "Cultural Revolution”. ${ }^{1}$ Yet attempts online to deliberate those historic lessons, or examine the legacy of the period's terror and violence - it swept up an entire generation in ideological-driven turmoil, scarring communities, and creating deep rifts in society - met with swift censorship. A Baidu keyword search for 'Cultural Revolution' 文革 in May turned up the odd slideshow or piece on historical nostalgia, but no critical discussions or detailed histories of what transpired. The silencing of discussion has affected historical memory - which is, surely, one of the objectives, given the Party's culpability in the abuses of the period.

In a vox pop clip aired on the history channel of Hong Kong's Phoenix Television 凤凰历史, a reporter asked student-aged Chinese citizens some basic questions about the Cultural Revolution - how they might describe it in one word, for example - and received a dizzying array of contradictory answers. ${ }^{2}$ One young interviewee told the reporter: 'I don't understand 


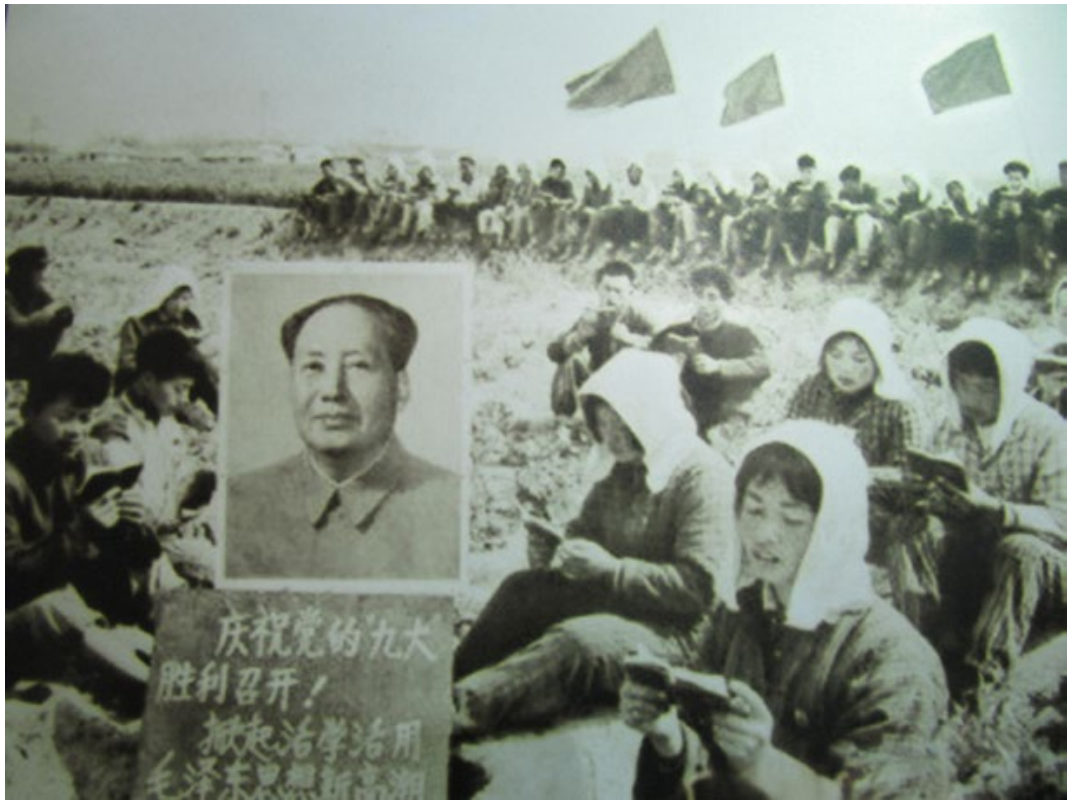

Cultural Revolution political study session

Source: klarititemplateshop.com

ancient times'. Another thought the Cultural Revolution was connected to the Nanjing Massacre of 1937-1938, when occupying Japanese soldiers raped and/or murdered hundreds of thousands of civilians. Some, thanks to family stories for example, knew more than others, but in general interviewees blamed their ignorance on the lack of public discussion and incomplete history texts. Not surprisingly, when Phoenix Television's posted an account of the exercise on Weibo, the authorities quickly deleted it.
The CCP's reticence about the Cultural Revolution's anniversary reflects its approach to handling inconvenient aspects of its history in general: first, by distancing itself, and then by blocking any further probing. On the fortieth anniversary of Mao Zedong's death on 9 September, the Party followed a similar strategy. While state-run media issued conditional praise for the 'Great Helmsman', President Xi Jinping made no mention of the anniversary, nor was there any official tribute. 
Slideshows of the leader on Sohu 搜狐 and Sina 新浪, blocked the 'user comments' option to prevent controversial comments.

China's burgeoning online neoMaoist communities, however, took advantage of the official silence to discuss both the Cultural Revolution and Mao in favourable terms. According to the Global Times, on 9 September over two million online users participated in a virtual flower-laying campaign on
WeChat in remembrance of Mao. ${ }^{3} \mathrm{~A}$ commentary that ran on the neo-Maoist website Utopia 乌有之乡 proclaimed, 'Mao was a great Chinese leader who changed the country and the world. This is a fact that even Mao's enemies have to admit.' But the title of the piece was even more revealing: 'All errors originate from the assessment that Mao made errors' 一切错误源于认 定毛主席有错误. ${ }^{4}$ 
This text is taken from China Story Yearbook 2016: Control, edited by Jane Golley, Linda Jaivin and Luigi Tomba, published 2017 by ANU Press, The Australian National University, Canberra, Australia. 